\title{
Evaluation of a Photovoltaic Energy System Applied to a Drip Irrigation System
}

\author{
Soni Willian Haupenthal ${ }^{1}$, Jair Antonio Cruz Siqueira ${ }^{1}$, Luciene Kazue Tokura ${ }^{1}$, \\ Carlos Eduardo Camargo Nogueira ${ }^{1}$, Marcio Antonio Vilas-Boas ${ }^{1}$, Lais Fernanda Juchem do Nascimento ${ }^{1}$ \\ \& Everton Ortiz Rocha ${ }^{1}$ \\ ${ }^{1}$ State University of West Paraná, Cascavel, Brazil \\ Correspondence: Soni Willian Haupenthal, Engineering of Energy in Agriculture, State University of West \\ Paraná, Cascavel, 2069, CEP 85.819-130, Bairro Faculdade, Brazil. Tel: 55-45-3220-3151. E-mail: \\ soniwillian@hotmail.com
}

Received: April 22, 2018

Accepted: May 26, $2018 \quad$ Online Published: July 15, 2018

doi:10.5539/jas.v10n8p43

URL: https://doi.org/10.5539/jas.v10n8p43

\begin{abstract}
This work aimed to evaluate the performance of a drip irrigation system with photovoltaic energy directly connected to the water pumping system through the irrigation uniformity coefficients using the statistical quality control, with the control chart of Shewhart. The experiment was conducted at the State University of West Parana (UNIOESTE), campus of Cascavel, in the Project CASA (Center of Alternative Energy System Analysis), during six days of open sky. The irrigation system contained four lines with 18 drippers each, collecting the flow of each dripper for five minutes, along with the parameters of temperature and solar radiation. In the energy part, the current and the voltage generated by the panel were analyzed. The main results allowed to evaluate that the flows of the drippers showed changes directly proportional to the decrease or increase of the radiation. Even with the changes in radiation levels during the collection period, the system obtained excellent process capability according to the analyzes of the distribution uniformities. It was also concluded that there was a significant relationship between the coefficients (CUC, DUC and CV) with the process capacity of the flow data. The control plot was adequate to diagnose the treatments. Statistical control proved to be effective for the determination of process variability, thus recommending the use of a drip irrigation system with a solar photovoltaic system directly connected to the pump on open sky days with few clouds due to the lower variability in relation to the graph of control and greater uniformity of water distribution.
\end{abstract}

Keywords: localized irrigation, uniformity coefficient, solar energy, control chart

\section{Introduction}

Global warming has been occurring in recent decades and we can see the increase in global temperatures, which is characterized by air heating, which is caused by the accumulation of gases released into the atmosphere and the heating of ocean temperatures (Lise \& Laan, 2015). The burning of fossil fuels is mainly responsible for the emission of greenhouse gases that change the climate (Joensuu \& Sinkko, 2015).

To meet the energy needs, several countries adopt fossil fuels on a large scale for their production. With these mitigating factors, there is a real need to reduce the emission of polluting gases, as stated in the Kyoto protocol, and an alternative is the use of new sources of energy, such as renewable energy, such as photovoltaics (Kalogirou, 2009). Consisting that the use of these energy sources is a strategy that can potentially reduce greenhouse gases (Thornley, Röder, \& Whittaker, 2015).

Therefore, photovoltaic energy, in addition to supplying the energy needs, brings with it the clean and renewable energy mentality, which is easily available (Bardi, Asmar, \& Lavacchi, 2013; Carroquinho, Dufo-López, \& Bernal-Aguntín, 2015). This energy source is the most promising, especially to face the energetic crises expected for the next few years (Tomalsquim, 2003).

One of the benefits of energy generation from the sun is accessibility in remote places, where the costs of implementing a conventional network are unfeasible, in the case of numerous rural properties (Martins \& Pereira, 2011). 
According to Chilundo (2014) low need for maintenance of equipment, relative ease of installation and displacement, autonomous operation, adaptation to the greater need of water with the joint increase of solar radiation values and ease of cleaning, make the photovoltaic energy system a great option for supply for irrigation purposes.

Thus, the connection between an efficient irrigation system and the renewable energy system is of great importance for solving global problems. In this study, the use of photovoltaic panels for irrigation has been shown to be of importance in areas of plant and fruit cultivation (Kelley, Gilbertson, \& Sheikh, 2010; Reca, Torrente, López-Luque, \& Martínez, 2016).

Localized irrigation is considered one of the most efficient methods (Verma, Tsephal, \& Jose, 2004; Upadhyay, 2003). And with the advancement of irrigation systems technologies and the increasing demand for water by human activities, the search for such irrigation methods, which consume less resources and provide better results in productivity and quality, has been accentuated. In this way, drip irrigation has gained space, especially in the last 15 years (Sá, 2013).

This method of irrigation allows a reduction in the period to irrigate the crop, improve the locality of the water to be available near the root zone of the plant, supplying the water requirement of the crop (Ranquet, Müller, \& Perona, 2016).

The coefficients of uniformity have significant importance in the planning of a drip irrigation system, since the uniformity of water application and the irrigation management used significantly affect the yield of the crop and the water used (López-Mata, Tarjuelo, Juan, Ballesteros, \& Domínguez, 2010).

There are several methods to determine the coefficients that evaluate the uniformity of water application in a drip system, among them the Christiansen uniformity coefficient (CUC) (Christiansen, 1942) and the distribution uniformity coefficient (CUD) (Merrian \& Keller 1975; Montgomery, 2009).

Another analysis that can be done, aiming at a better efficiency of the drip irrigation system is using statistical quality control, which is defined by checking the process, establish standards, compare performances, verify and study deviations, finding solutions pointing to system improvements (Frigo, 2014).

In addition, the most used methods to perform statistical quality control by graphs are: Shewart, weighted exponential moving average (EWMA) and cumulative sum chart (CUSUM).

The Shewart plot method is characterized by its individual means, simplicity of construction and analysis of the results (Frigo, 2014), by such factors was chosen for the statistical analysis of the experiment but has as negative aspect the slowness in the presentation of small variations in the processes (Costa, 2008).

Therefore, the objective of this analysis was to evaluate a drip irrigation system with photovoltaic energy directly connected to the pump. Performing the dripper collections by the methods of Keller and Karmelli (1975) and by the method of Deniculi et al. (1980). Determining the CUC and the CUD analyzed them by means of a control chart, by the Shewart method.

\section{Material and Methods}

The irrigation system for this research was tested at the State University of West of Paraná (UNIOESTE), in Cascavel, PR, with Latitude $24^{\circ} 59^{\prime}$ South, Longitude $53^{\circ} 23^{\prime}$ West and altitude of 750 meters and with average irradiance of $4.80 \mathrm{kWh} \mathrm{m}^{-2} \mathrm{day}^{-1}$, according to the Sundata Program (CRESESB, 2017).

Since Brazil, due to its privileged location, possesses adequate values of averages of solar irradiance throughout its territory. Since its indices for any national region are larger than most European countries, where photovoltaic energy system projects have a much greater appeal (Martins, Guarnieri, \& Pereira, 2008).

The measurements of the variables were of solar irradiance, temperature, current and voltage generated by the panel and flow of the drippers. Using a three-module photovoltaic system of the brand Solartec KS50 with nominal power of $50 \mathrm{~W}$, as shown in Figure 1, connected in parallel with the intention of raising the current and maintaining the voltage at $12 \mathrm{~V}$ direct current connected directly to the pump diaphragm of the brand SHURFLO, model 8000 with a maximum flow rate of $490 \mathrm{~L} \mathrm{~h}^{-1}$ and with a manometric capacity of 21.11 mca, the water being available in a water box of 100 liters, suctioning the water to the main line, deriving in 4 lines of drippers of the Naandanjain Irrigation brand, Topdrip PC \& PC AS model with spacing of 30 centimeters between the drippers, with operating pressure of 4.8 to $30.6 \mathrm{mca}$, and flow of 1.0, 1.6, 2.0, 2.2 $\mathrm{L} \mathrm{h}^{-1}$, according to the pressure. 


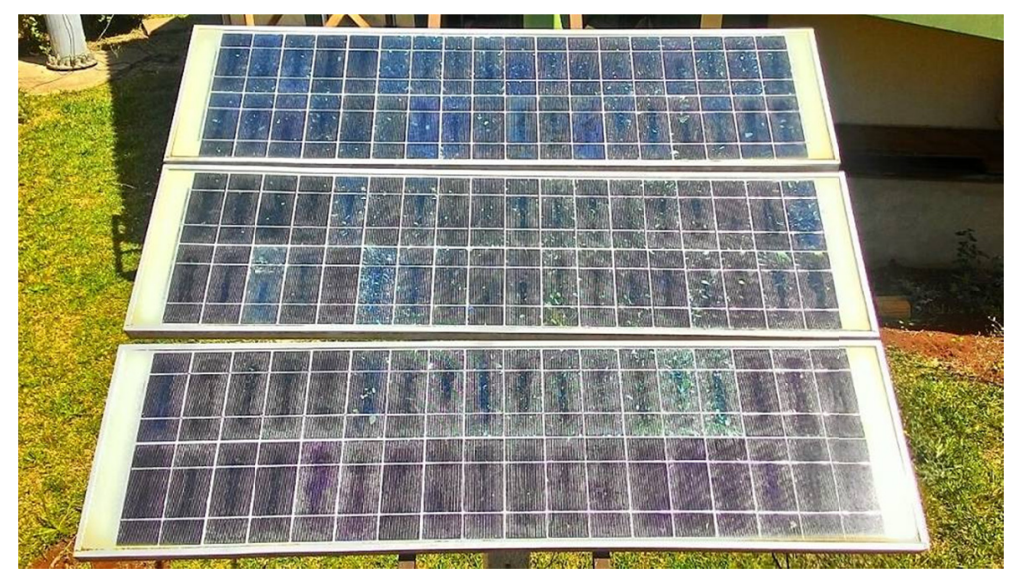

Figure 1. Photovoltaic system used in power supply

For the measurement of the electric energy supplied by the photovoltaic system for the water pump, two multimeters of the Instrutherm brand were used.

One of the multimeters was connected in parallel with the output terminals of the photovoltaic panel for the measurement of the direct current voltage, and the other multimeter connected in series with the hydraulic pump for the current measurement consumed by the load, as shown in Figure 2.

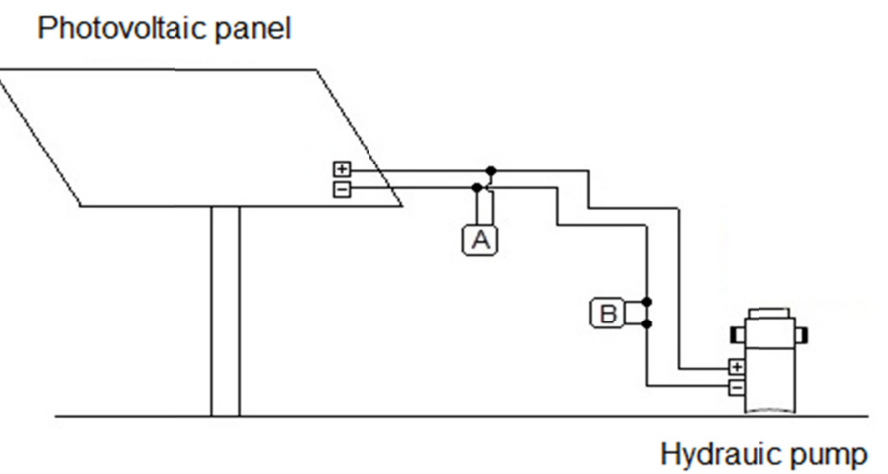

Figure 2. Electrical system to measure current $(A)$ and voltage $(V)$

Note. $\mathrm{A}=$ Multimeter to measure system voltage; $\mathrm{B}=$ Multimeter used to measure the electric current.

Since the voltage and current of the photovoltaic system are measured during the tests, with duration of 5 minutes, calculating the hourly average and later the energy produced using Equation 1,

$$
\mathrm{Wh}=\mathrm{V} \cdot \mathrm{A} \cdot \mathrm{h}
$$

Where, $\mathrm{Wh}=$ Energy produced (Watt hour); $\mathrm{V}=$ Voltage (Volt); $\mathrm{A}=$ Current (Ampere); $\mathrm{h}=$ Time (Hours)

While the solar irradiance data were collected with the MES-100 solar energy meter with a scale of up to 2000 $\mathrm{Wm}^{-2}$, at the same instant of the temperature measurement by the Hikari 4-in-1 decibelmeter, luximeter, temperature and humidity meter, model HTM-401.

The collection methodology follows the references of Keller and Karmelli (1975), and Deniculi et al. (1980), and the irrigation system was placed parallel to the ground inside the project CASA (Figure 3), being characterized as indoor, without the interference of the variations of intempéries, being the dripping tubes supported by cables. A reservoir with a capacity of 100 liters was installed to supply the system and the photovoltaic panels near CASA to supply the power requirement of the diaphragm pump. 


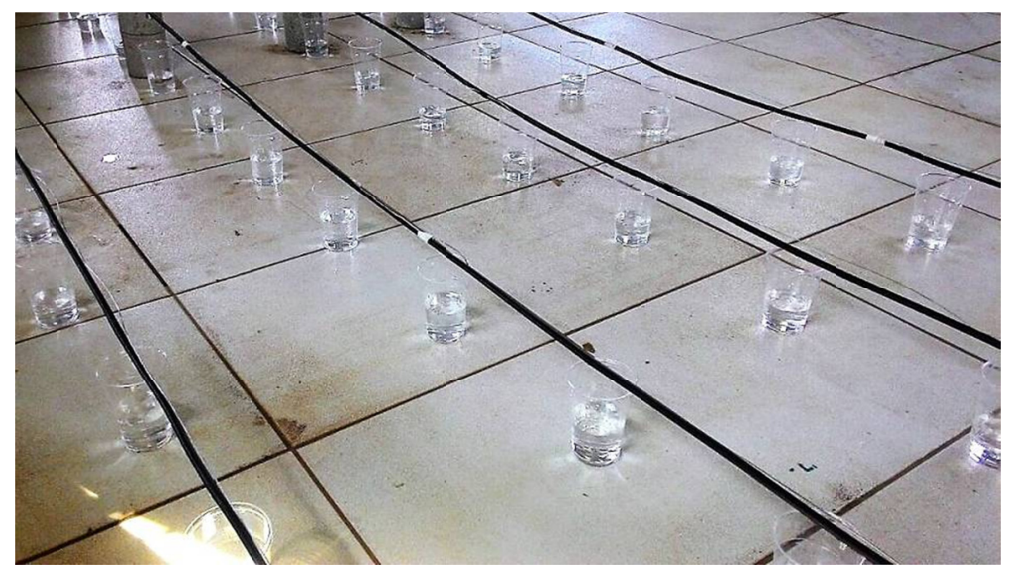

Figure 3. Drip irrigation system for collecting the flow through the emitters

At the outlet of the tank was installed a screen type filter. A main line with a span of 540 centimeters was connected after the filter. In the main line, four lateral lines, spaced 40 centimeters apart, were connected. Each lateral line is composed of a drip tube, and it contains 18 in-line drippers, spaced every 30 centimeters, as show in Figure 4.

Twenty-seven experiments were performed with the drip system connected directly to the photovoltaic panel during the 5-minute interval, where the tests ranged from 9:45 am to 4:00 pm. Afterwards, the data were analyzed by uniformity analysis, with units of the response variables of $\mathrm{L} \mathrm{h}^{-1}$ for the flow of drippers and Wh for the energy produced by the electric system.

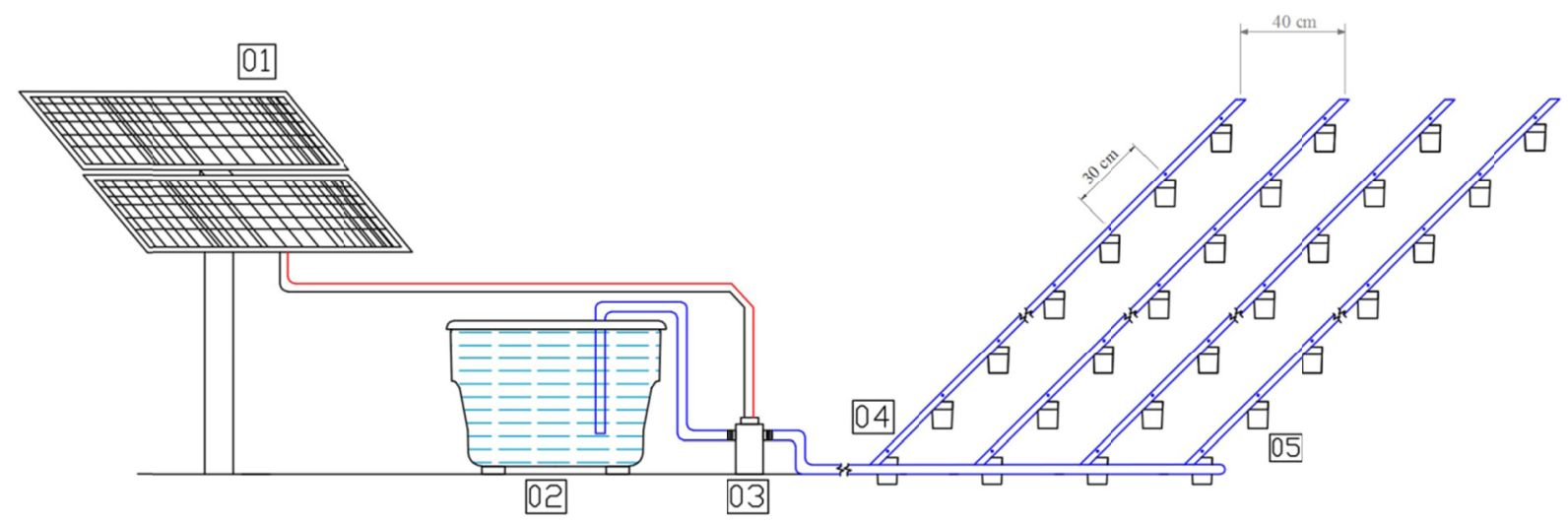

Figure 4. Layout of the drip irrigation system with photovoltaic energy

Note. $01=$ Photovoltaic mode; $02=$ Water tank; $03=$ Pumping system; $04=$ dripper; $05=$ Colector.

One of the data collection methodologies was to select 16 collection points, located on the first lateral line dripper, the dripper at $1 / 3$ of the total length of the lateral line, the dripper at $2 / 3$ of the length and the last dripper (Keller \& Karmeli, 1975).

For the Denículi (1980) methodology, 32 drippers were selected for collection, located in the first 1/7, 2/7, 3/7, $4 / 7,5 / 7,6 / 7$ of the beginning of the line and the last dripper, for the 4 lateral lines.

The selected lateral lines follow the same criterion $\left(1^{\mathrm{a}}, 1 / 3,2 / 3\right.$ and the last one) however, since the experiment has only four lines, this criterion was ruled out.

For the collection of water volume, the recommended for both methodologies was followed. All the collectors were positioned at the same time at the collection points while the system was in operation. For this experiment a collection time of 5 minutes was determined after the end of the time, all were removed at the same time and the volume of water of each collector was measured using a graduated cylinder. 
The electrical voltage and electric current in the pumping system were measured at the same time as the dripper tests, during the water collection period in the collectors.

The water comes from a water box placed outside the project CASA at ground level. With the photovoltaic panels connected directly to the water pump for the power supply, the project has its operation administered.

Then, from the hydraulic pump, the water is pumped from the hoses to the dripper located inside the CASA project, thus determining the coefficients of uniformity of the drippers.

Consisting that at the same time of collecting dripper data, the levels of solar radiation, ambient temperature, voltage and electric current were collected during the operation of the pump.

The criteria for assessing the uniformity of water application of the system were the coefficient of variation (CV) of the emitter on the lateral line, the Distribution Uniformity Coefficient (DUC) and the Christiansen's Uniformity Coefficient (CUC) and later analyzing them from the control chart.

The Christiansen's Uniformity Coefficient (CUC), proposed by Christiansen (1942), is one of the most used, since it adopts the absolute mean deviation as a measure of dispersion, as can be observed in Equation 2,

$$
\mathrm{CUC}=\left\{1-\left[\sum\left(\mathrm{L}_{\mathrm{i}}-\mathrm{L}_{\mathrm{m}}\right) / \mathrm{N} \cdot \mathrm{L}_{\mathrm{m}}\right]\right\} \times 100
$$

Where, CUC $=$ Christiansen's Uniformity Coefficient $(\%) ; \mathrm{L}_{\mathrm{i}}=$ Flow of each dripper $\left(\mathrm{L} \mathrm{h}^{-1}\right) ; \mathrm{L}_{\mathrm{m}}=$ Average flow of drippers $\left(\mathrm{L} \mathrm{h}^{-1}\right) ; \mathrm{N}=$ Number of drippers.

For the classification of CUC data, the proposal of Bernardo, Soares, and Mantovani (2008) that classify the uniformity of the application according to Table 1 .

Table 1. Classification of the Christiansen's Uniformity Coefficient (CUC)

\begin{tabular}{ll}
\hline Classification & CUC \\
\hline Excelent & $>90$ \\
Good & $80-90$ \\
Regular & $70-80$ \\
Poor & $60-70$ \\
Unacceptable & $<60$ \\
\hline
\end{tabular}

Source: Bernardo, Soares, and Mantovani (2008).

The Distribution Uniformity Coefficient (DUC) is defined as the measure of the water distribution that relates the fourth area $\mathrm{f}$ the total area and receives less water with the applied average bladder the entire area receives at least the required actual blade, a low DUC value indicates excessive percolation loss, which can be seen below in Equation 3,

$$
\operatorname{DUC}=\left(\mathrm{L}_{\mathrm{q}} / \mathrm{L}_{\mathrm{m}}\right) \times 100
$$

Where, DUC = Distribution uniformity coefficient (\%); $\mathrm{L}_{\mathrm{q}}=$ mean value of $25 \%$ of the lowest flows $\left(\mathrm{L} \mathrm{h}^{-1}\right) ; \mathrm{L}_{\mathrm{m}}$ $=$ Means of all flows $\left(\mathrm{L} \mathrm{h}^{-1}\right)$.

In relation to the classification of the uniformity coefficient data, the standard ASABE (American Society of Agricultural and Biological Engineers) (1996) was used, classifying the uniformity of the application according to Table 2 .

Table 2. Classification of the distribution uniform coefficient (DUC)

\begin{tabular}{ll}
\hline Classification & DUC \\
\hline Excelent & $>90$ \\
Good & $80-90$ \\
Regular & $70-80$ \\
Poor & $60-70$ \\
Unacceptable & $<60$ \\
\hline
\end{tabular}


Another important parameter in localized irrigation is the coefficient of variation (CV), proposed by Keller and Bliesner (1990), presented in Equation 4. This parameter is evaluated because the emitters have reduced dimensions that hinder the precision in their manufacture. The variations in flow rates, caused by constructive failures, present normal distribution, thus, it is allowed the use of statistical concepts corresponding to this distribution for quantitative conclusions.

$$
\mathrm{CV}=\left(\mathrm{s} / \mathrm{Q}_{\mathrm{med}}\right) \times 100
$$

Where, $\mathrm{CV}=$ Coefficient of variation $(\%) ; \mathrm{s}=$ Standard deviation $\left(\mathrm{L} \mathrm{h}^{-1}\right) ; \mathrm{Q}_{\mathrm{med}}=$ Means of all flows $\left(\mathrm{L} \mathrm{h}^{-1}\right)$.

For drippers to be classified into quality categories, the coefficient of variation (CV) is used. Thus, the issuers are classified according to Table 3 .

Table 3. Coefficient of variation $(\mathrm{CV})$ of the emitters

\begin{tabular}{lll}
\hline Type of sender & $\mathrm{CV}(\%)$ & Interpretation \\
\hline Transmitter with point output & $<5$ & Great \\
& $5-7$ & Medium \\
& $7-11$ & Marginal \\
& $11-15$ & Deficient \\
& $>15$ & Unacceptable \\
\hline
\end{tabular}

To monitor the uniformity coefficients, it was used the Shewart control chart, which requires the calculation of the Upper Control Limit (UCL) and the Lower Control Limit (LCL), by Equations 5 and 6.

$$
\begin{gathered}
\mathrm{UCL}=\mu+\left(3 \mathrm{MA} / \mathrm{d}_{2}\right) \\
\mathrm{LCL}=\mu-\left(3 \mathrm{MA} / \mathrm{d}_{2}\right)
\end{gathered}
$$

Where, UCL $=$ Upper Control Limit; LCL $=$ Lower Control Limit; $\mu=$ Average; MA $=$ Mobile range of observations; $\mathrm{d}_{2}=$ Pre-determined tabular value (according to the number of repetitions).

\section{Results and Discussion}

The results presented in Table 4 refer to the energy variables, in Wh and the mean flow rate by the drippers in $\mathrm{L}$ $\mathrm{h}^{-1}$, together with the descriptive statistics. Analyzing the data, we can observe the variability in the energy production for the six days of collection, this being the result of the photovoltaic system being connected live in the diaphragm pump, where the conditions of solar irradiance interfered directly in the production and supply of energy, the system directly connected does not make use of a load controller.

As for the values of standard deviation, we can highlight the lower value that occurred on the first day of collection, where we had cloudy sky with little variability of the irradiance, resulting in lower average energy production and lower average consequence of flow, which remained stable for all days of collection even with the variation in energy supply, because the emitters used are self-compensating, where, according to Teixeira (2006), this model presents distinctions when compared to other models of drippers, being produced for supply

\begin{tabular}{|c|c|c|c|c|c|c|}
\hline & 1st Day & 2nd Day & 3rd Day & 4th Day & 5th Day & 6th Day \\
\hline Mean Energy (Wh) & 4.45 & 4.96 & 5.19 & 4.7 & 5.28 & 4.96 \\
\hline SD Energy (Wh) & 0.08 & 0.28 & 0.29 & 0.40 & 0.11 & 0.24 \\
\hline CV Energy (\%) & 1.92 & 5.76 & 5.11 & 8.59 & 2.24 & 4.88 \\
\hline Mean Flow $\left(\mathrm{L} \mathrm{h}^{-1}\right)$ & 3.56 & 3.63 & 3.71 & 3.62 & 3.88 & 3.69 \\
\hline SD Flow $\left(\mathrm{L} \mathrm{h}^{-1}\right)$ & 0.009 & 0.023 & 0.008 & 0.033 & 0.011 & 0.020 \\
\hline CV Flow (\%) & 0.24 & 0.62 & 0.21 & 0.92 & 0.30 & 0.56 \\
\hline
\end{tabular}
even with increasing or decreasing service pressure values.

Table 4. Descriptive Statistics for mean energy produced and mean flow of drippers

Note. $\mathrm{SD}=$ standard derivation, $\mathrm{CV}=$ coefficient of variation.

Table 5 shows the average values of solar irradiance and the supply of current and voltage of the photovoltaic panel, observing that with the increase of the irradiance, an increase in the values of current and voltage is 
detected, noting that on the sixth day of collection we have a value of $914.67 \mathrm{Wm}^{-2}$, but smaller values of voltage and current when compared to the second and third day, being this factor justified by the increase of the irradiance or ambient temperature, which causes increase of the temperature of the photovoltaic cells, reducing their efficiency (Pinho \& Galdino, 2014).

Considering the voltage data, we can emphasize that the average voltage was $19.50 \mathrm{~V}$, and when confronted with the nominal voltage value of the $12 \mathrm{~V}$ hydraulic pump, we provide a higher capacity of the pump, but in contrast systems with voltage above the required voltage tend to damage the equipment, so it would be advisable to use a load controller to match the voltages.

Table 5. Mean collected from Irradiance, current and voltage

\begin{tabular}{llll}
\hline & Mean Solar Irradiace $\left(\mathrm{Wm}^{-2}\right)$ & Mean Current $(\mathrm{A})$ & Mean Voltage $(\mathrm{V})$ \\
\hline $1^{\circ}$ day & 618.00 & 2.88 & 19.52 \\
$2^{\circ}$ day & 893.80 & 3.12 & 19.70 \\
$3^{\circ}$ day & 888.60 & 3.14 & 19.78 \\
$4^{\circ}$ day & 811.17 & 2.97 & 19.00 \\
$5^{\circ}$ day & 979.67 & 3.23 & 19.60 \\
$6^{\circ}$ day & 914.67 & 3.02 & 19.37 \\
\hline
\end{tabular}

To evaluate the processes in a more efficient way, the elaboration of the control chart was constituted, once the process variabilities can be analyzed more precisely. To use the control charts, we must submit the data to normality analysis, which should be normally distributed and under control. Therefore, the Anderson-Darling, Ryan-Joiner and Kolmorogov-Smirnov tests were performed and the interdependence among the data through the self-study study.

Figure 5 shows the control graph for the energy responses produced.

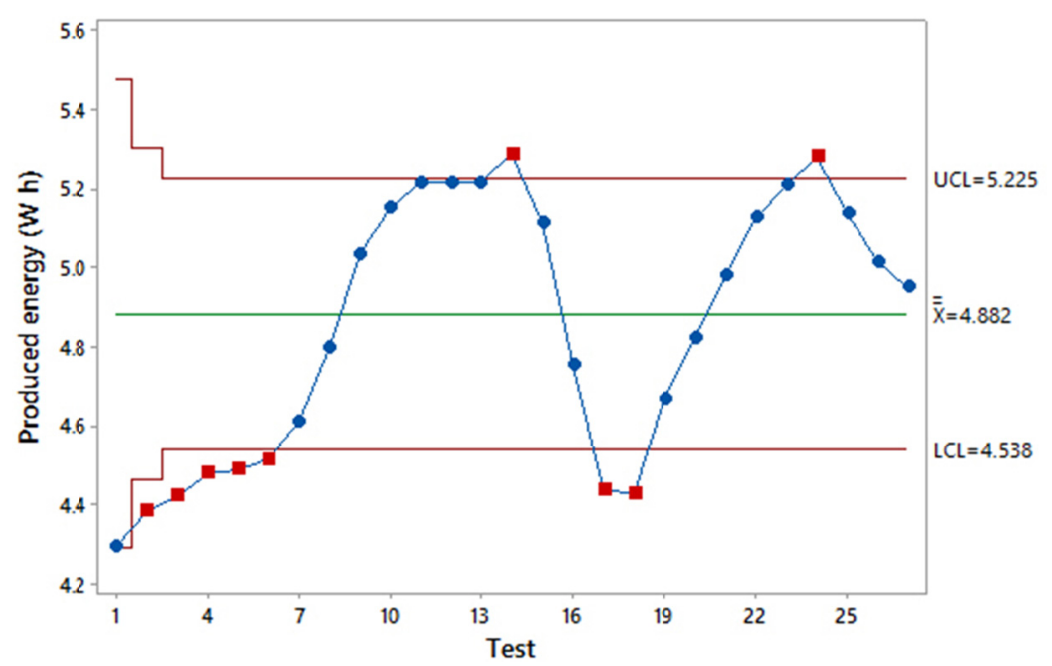

Figure 5. Shewhart control graph for energy produced (W h)

In analyzing the Shewhart graph for the energy produced, the process was not kept under control, that is, it has points both below and above the limits, where the points below the limit are that at the time of data collection, it was partially with low values of irradiance, ranging from 526 to $679 \mathrm{Wm}^{-2}$, resulting in low values of energy produced, ranging from $4,293 \mathrm{~W}$ h to $4,495 \mathrm{~W}$ h respectively, also reflected in the test 17 and 18 , which were collected at the hours of 09:45 and 10:30 am, with values of 624 and $761 \mathrm{Wm}^{-2}$ respectively.

For the values above the Upper Control Limit, they are due to the excess of irradiance, exceeding in both cases the $1000 \mathrm{Wm}^{-2}$, resulting in high current and voltage values generating a higher energy output. 
In relation to the water distribution uniformities, calculated by the CUC and DUC coefficients, following the Keller and Karmeli (1975), and Denículi (1980) methodologies, such values together with the descriptive statistics are shown in Table 6 and 7, respectively.

Table 6. Descriptive statistics of the coefficients of uniformity by the method of Keller and Karmeli (1975)

\begin{tabular}{lllllll}
\hline & 1st Day & 2nd Day & 3rd Day & 4th Day & 5th Day & 6th Day \\
\hline Mean CUC & 98.75 & 99.12 & 99.09 & 98.77 & 98.78 & 99.00 \\
SD CUC & 0.16 & 0.27 & 0.35 & 0.21 & 0.16 & 0.04 \\
CV (\%) CUC & 0.16 & 0.28 & 0.35 & 0.22 & 0.17 & 0.04 \\
Mean DUC & 97.91 & 98.62 & $98, .45$ & 97.60 & 98.45 & 98.51 \\
SD DUC & 0.52 & 0.25 & 0.70 & 0.94 & 0.21 & 0.15 \\
CV (\%) DUC & 0.53 & 0.26 & 0.70 & 0.96 & 0.22 & 0.16 \\
\hline
\end{tabular}

Note. $\mathrm{SD}=$ standard derivation, $\mathrm{CV}=$ coefficient of variation.

Table 7. Descriptive statistics of the coefficients of uniformity by Deniculi's method (1980)

\begin{tabular}{lllllll}
\hline & 1st Day & 2nd Day & 3rd Day & 4th Day & 5th Day & 6th Day \\
\hline Mean CUC & 98.76 & 99.11 & 99.09 & 98.88 & 98.88 & 99.97 \\
SD CUC & 0.10 & 0.39 & 0.26 & 0.20 & 0.13 & 0.14 \\
CV (\%) CUC & 0.11 & 0.40 & 0.26 & 0.20 & 0.13 & 0.15 \\
Mean DUC & 97.79 & 98.13 & 98.01 & 97.71 & 98.59 & 98.58 \\
SD DUC & 0.16 & 0.24 & 0.64 & 0.39 & 0.18 & 0.22 \\
CV (\%) DUC & 0.17 & 0.25 & 0.65 & 0.40 & 0.19 & 0.23 \\
\hline
\end{tabular}

Note. $\mathrm{SD}=$ standard derivation, $\mathrm{CV}=$ coefficient of variation.

It was observed that all treatments presented high levels of uniformity, above $90 \%$, being classified as excellent according to Bernardo, Soares, and Mantovani (2008), the values are similar to those presented by Santos et al. (2012), who analyzed a system of drip irrigation yielding values of $95.12 \%$ for CUC and $98.34 \%$ for DUC, corroborated with the results presented by Hermes et al. (2014), where it used drip irrigation with residual water use of cassava, obtaining values higher than $90 \%$ for all coefficients.

In a research in which a drip tube was used, for a period of 1620 hour, Puig-Bargués et al. (2010) found an average distribution uniformity of $90 \%$ with self-compensating emitter, however, at the end of each irrigation period, the emitters were washed.

Klein et al. (2015) using a drip system with different pressures and different concentrations of fertilizers, obtaining CUC above 90\% for all evaluations. Borssoi, Villas-Boas, Reisdörfer, Hernandez, and Follador (2012) evaluated the uniformity coefficient of a drip system at different pressures, reaching DUC values above $90 \%$.

When comparing both methodologies regarding the uniformity values, for both CUC and DUC, we reach practically analog values, but comparing the methodologies, we emphasize that the higher the number of drippers evaluated the more correct will be the coefficients (R. A. Silva \& A. M. Silva, 2003).

Analyzing the standard deviation separately, we found that there was little variability, based on information below $10 \%$ of $\mathrm{CV}$ values indicating homogeneous data.

For values below 5\% the data are classified as excellent, thus defining the values of Tables 6 and 7 as acceptable and excellent with 95\% confidence (ASABE, 1996).

Figure 6 shows the Shewart control graphs for the CUC and DUC coefficients by the Keller and Karmeli (1975) methodology, and when we analyze, it is observed that the CUC values are all above $90 \%$, defining as excellent according to Bernardo, Soares, \& Mantovani (2008), the process is under control, although, according to Frigo (2014), between samples 1 and 6, a sequence of data, seven sequenced samples, would characterize as having no statistical control.

The distribution uniformity chart is not under control as it has a value below the lower limit, although it is still above $90 \%$. 
Figure 7 shows Shewart's control charts for the Deniculi (1980) methodology, stating that all values are overcontrolled for both CUDs and CUCs, so according to Bernardo, Soares, and Mantovani (2008), as well as excellent.
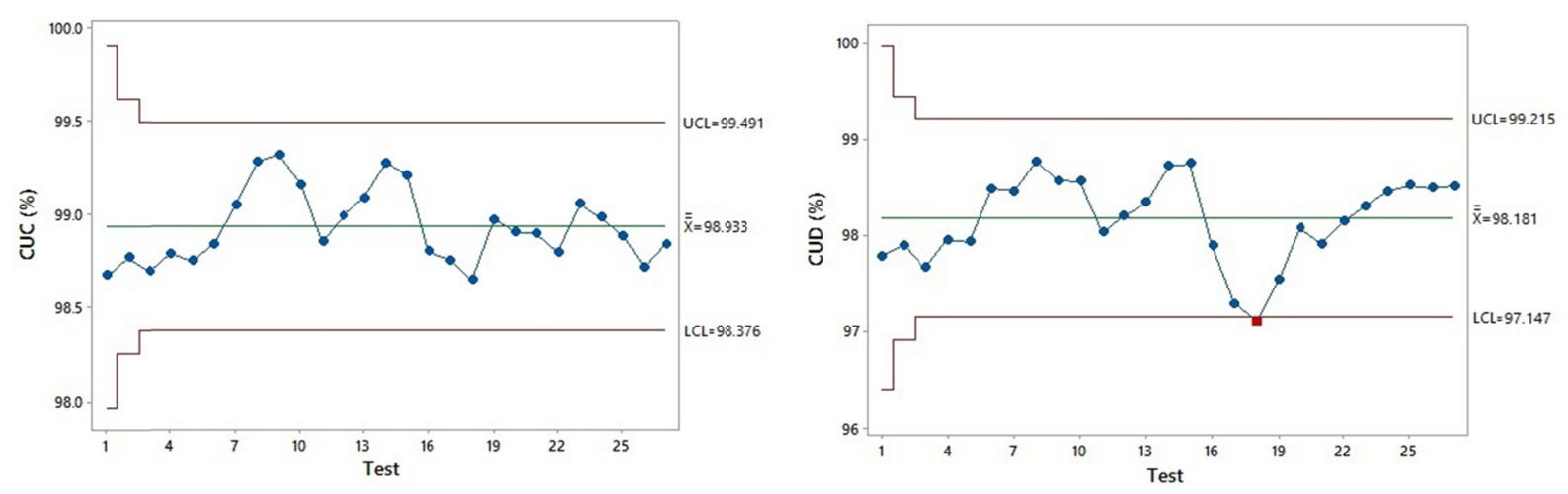

Figure 6. Shewhart control chart for Irrigation uniformity, Keller and Karmeli methodology (1975)
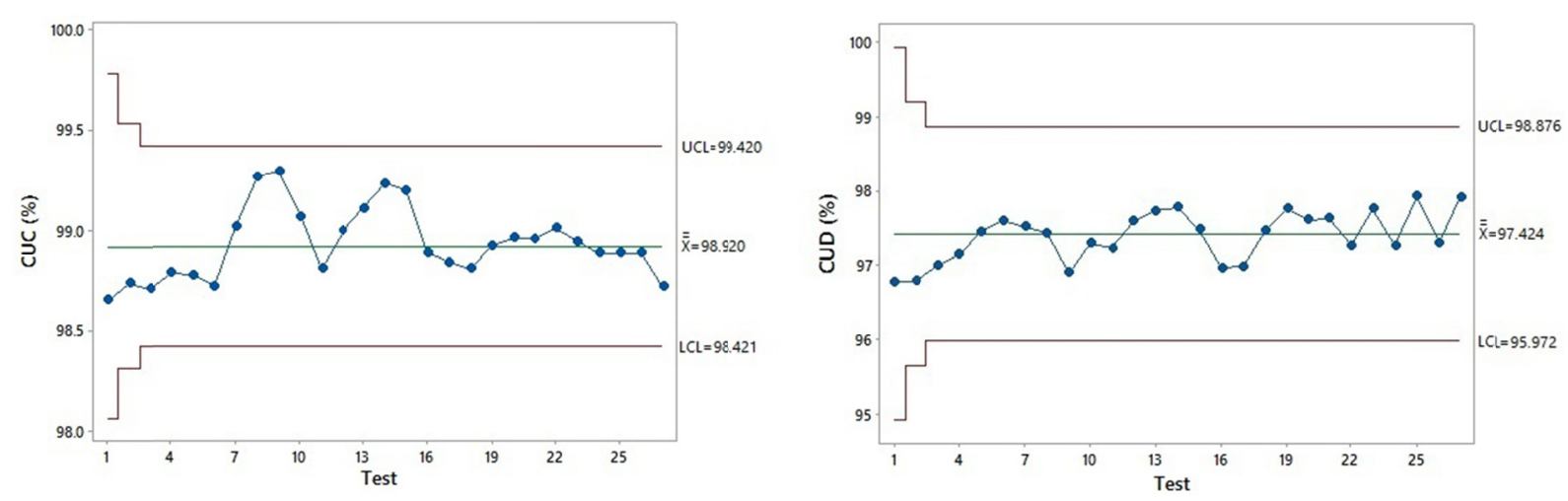

Figure 7. Shewhart control chart for Irrigation uniformity, Denículi methodology (1980)

In short, the tests are significant, diagnosing the variations of the energy production that were not kept under control, presenting values outside the control limits, due to the variations of irradiance, voltage and current, whereas for the irrigation system only one point was not under control, but characterized the process as a whole, within the limits, presenting values close to the midline and with little variability in the distribution of water by the drippers, since these are self-compensating.

The control charts can collaborate for a quality irrigation, rationalizing water, by analyzing the variability of the studied questions, emphasizing that Frigo et al. (2013), evaluated the effect of wind in a sprinkler irrigation system and the control chart tool, defined that the irrigation at night was more uniform, minimizing waste.

The studies done with drip systems and the use of control charts are supported by other authors such as Hermes (2014), and Hermes et al. (2015), who analyzed a drip system using Shewart's control charts for values below the lower limit, while Juchen, Suszek, and Vilas Boas (2013) obtained in their drip study for fertigated lettuce production values within limits, corroborated by Tessaro (2012) which analyzed a drip system with different hydraulic loads, concluding that all the treatments were excellent, being the two treatments with the highest uniformity $(\mathrm{CUC}=99.02 \%$ and $\mathrm{DUC}=98.69 \%)$ under statistical quality control.

Statistical quality control was studied by (Hermes et al., 2015) in a drip irrigation system and concluded that, the process capacity indicator is directly proportional to the increase of the system uniformity, being possible to monitor the control of the system irrigation within satisfactory limits.

In Figure 8 and 9 the linear regression graphs of the (CUC and DUC) coefficients in relation to the energy produced are shown, where we can observe that when the energy values are compared with the performance of the irrigation system, there is a low correlation, that is, the variations in energy supply during the tests did not significantly affect the uniformity performance in both methodologies, which remained above $90 \%$ in all 
analyzes, a study corroborated by Zago (2017), linear regression graphs of the uniformity comparison of the irradiance drip system, attenuated that there was no significant correlation.
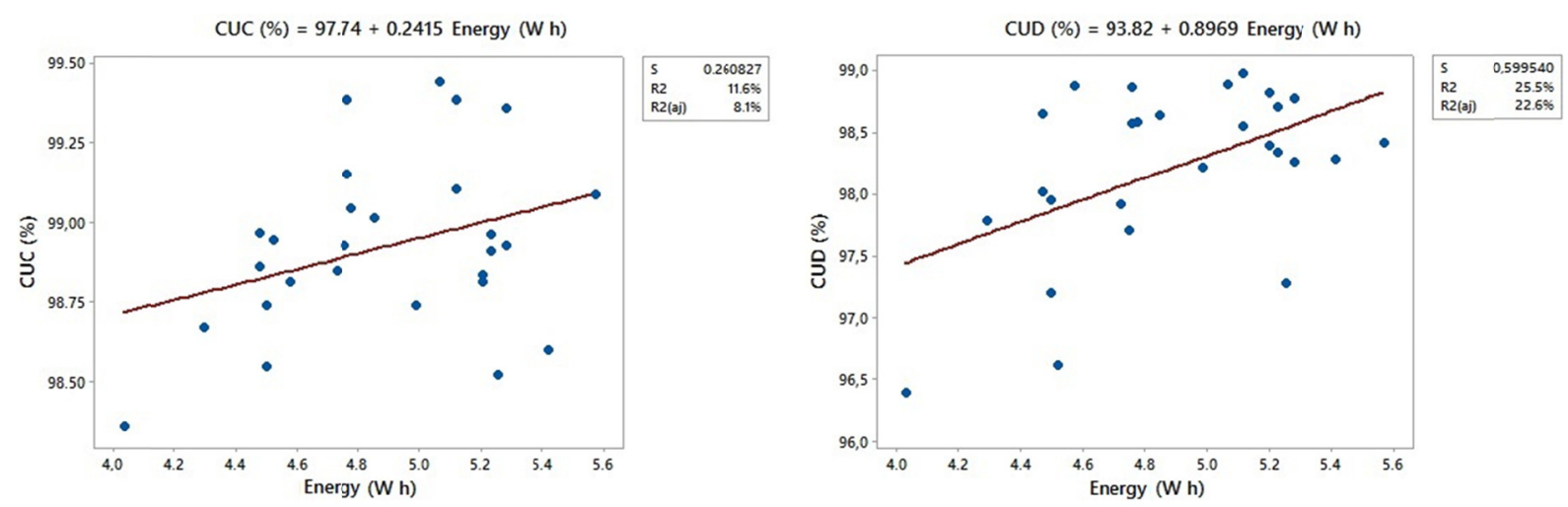

Figure 8. Linear regression graph between energy and uniformity coefficients (CUC and DUC) for Keller and Karmeli's method (1975)
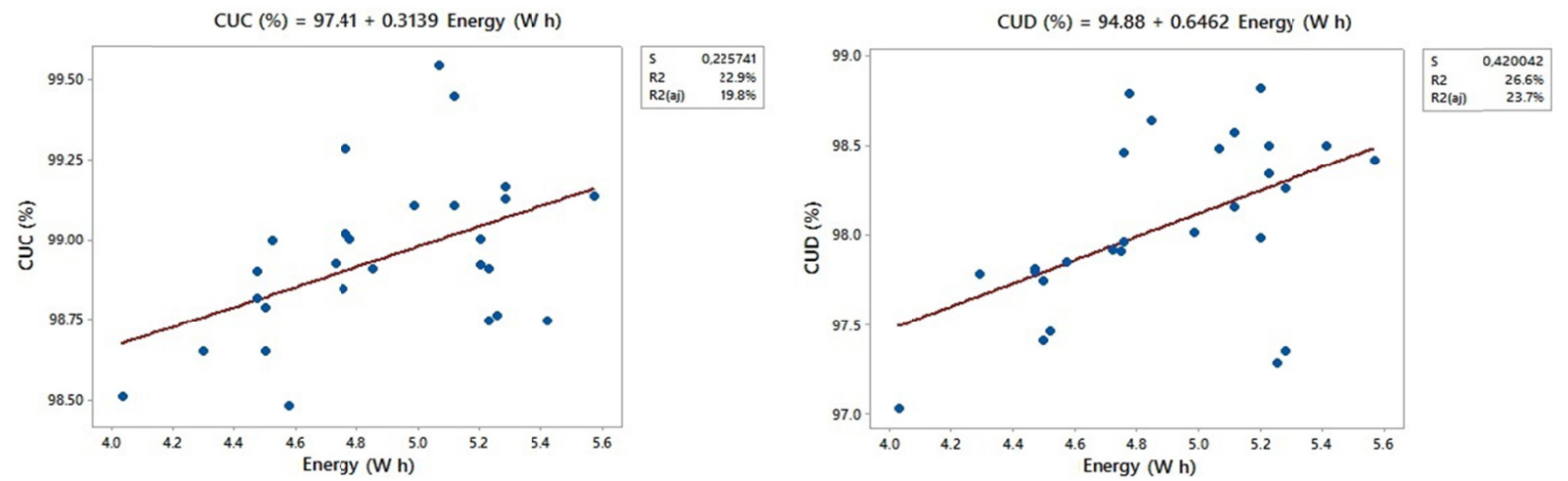

Figure 9. Linear regression graph between energy and uniformity coefficients (CUC and DUC) for Denículi’s method (1980)

In turn, Figure 10 shows the relationship between irradiance and energy production and comparing the variables we observed a significant correlation that reaches $71.1 \%$, that is, the changes of irradiance that occur during the period of data collection significantly affect the production and supply of energy by the photovoltaic panel. What was already expected since these magnitudes are directly proportional.

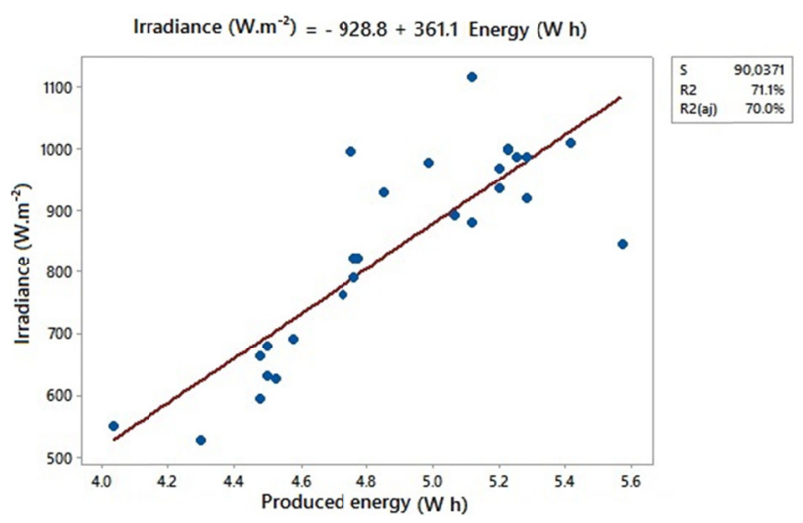

Figure 10. Linear regression graph between produced energy and irradiance 


\section{Conclusion}

From the results obtained, in the present experiment we conclude that in relation to the power supply, the nominal value of $12 \mathrm{~V}$ of the water pump was exceeded, where the average of $19.5 \mathrm{~V}$ was calculated, thus recommending the use of a load controller to avoid damaging the equipment.

As for the uniformity of distribution, the treatment was considered excellent by its values of $98.92 \%$ for the CUC according to the Keller and Karmeli's method and $98.94 \%$ for the Deniculi's methodology, in relation to the DUC we obtained $98.20 \%$ second Keller and Karmelli and 98.03\% following the Deniculi's methodology.

The control graphs were adequate to diagnose the data, classifying most of the uniformity processes as under control, different from the produced energy that was not kept under statistical control, diagnosing the interference of the irradiance in the energy supply, presenting values both below and above of control limits.

In sum, it is recommended to use the drip irrigation system with electric power supplied by photovoltaic panels connected directly to the water pump, in open sky days, obtaining a uniformity considered excellent, reaching values close to $99 \%$ of CUC and $98 \%$ of DUC, for both collection methodologies, with reliable results and according to statistical control techniques.

\section{References}

ASABE (American Society of Agricultural and Biological Engineers). (1996). Field evaluation of micro-irrigation Systems (pp. 792-797). St. Joseph, USA.

Bardi, U., Asmar, T., \& Lavacchi, A. (2013). Turning electricity into food: the role of renewable energy in the future of agriculture. Journal of Cleaner Production, 53, 224-231. https://doi.org/10.1016/j.jclepro.2013. 04.014

Bernardo, S., Soares, A. A., \& Mantovani, E. C. (2008). Manual de Irrigação (p. 625).

Borssoi, A. L., Vilas Boas, M. A., Reisdörfer, M., Hernandez, R. H., \& Follador, F. A. C. (2012). Water Aplication uniformity and fertigation in a dripping irrigation set. Revista Engenharia Agrícola, 32, 718-726. https://doi.org/10.1590/S0100-69162012000400011

Carroquino, J., Dufo-López, R., \& Bernal-Agustín, J. L. (2015). Sizing of off-grid renewable energy systems for drip irrigation in Mediterranean crops. Renewable Energy, 76, 566-574. https://doi.org/10.1016/j.renene. 2014.11.069

Chilundo, R. J. (2014). Sistema Fotovoltaico Aplicado à Irrigação de uma unidade agrícola de produção familiar (Unpublished master's thesis, Engenharia Elétrica, Universidade Federal do Ceará, Fortaleza).

Christiansen, J. E. (1942). Irrigation by sprinkling. Berkley: University of California.

Costa, A. F. B., Epprecht, E. K., \& Carpinetti, L. C. R. (2008). Controle Estatístico de Qualidade (2nd ed.). São Paulo: editora Atlas.

CRESESB (Centro de Referência para Energia Solar e Eólica Sérgio de Sálvio Brito). (2017). Retrived September 25, 2017, from http://www.cresesb.cepel.br/sundata/index.php

Denículi, W., Bernardo, S., Thiébaut, J. T. L., \& Sediyama, G. C. (1980). Uniformidade de distribuição de água, em condições de campo num sistema de irrigação por gotejamento. Revista Ceres, 27, 155-162.

Dillon, A. (2011). Do differences in the scale of irrigation projects generate different impacts on poverty and production? Journal of Agricultural Economics, 62, 474-492. https://doi.org/10.1111/j.1477-9552.2010. 00276.x

Frigo, J. P. (2014). Controle estatístico da qualidade na irrigação por aspersão (Unpublished doctoral dissertation, Universidade Estadual do Oeste do Paraná, Cascavel, Brasil).

Frigo, J. P., Vilas Boas, M. A., Frigo, E. P., Hermes, E., \& Tessaro, E. (2013). Irrigação diurna e noturna em um sistema de aspersão convencional em Palotina-PR. Irriga, 18, 318-327. https://doi.org/10.15809/irriga. $2013 \mathrm{v} 18 \mathrm{n} 2 \mathrm{p} 318$

Hermes, E., Vilas Boas, M. A., Gris, D. J., Frigo, E. P., Berger, J. S., Lins, M. A., \& Frigo, J. P. (2014). Irrigation with wastewater from cassava processing with different concentrations of suspended solids. Journal of Food Agriculture Environment, 12(1), 487-490. https://doi.org/10.1234/4.2014.4299

Hermes, E., Vilas Boas, M. A., Rodrigues, L. N., Mello, E. L., Goncalves, M. P., Lins, M. A., \& Berger, J. S. (2015). Process capacity index in drip irrigation with cassava wastewater processing. African Journal Agricultural Research, 10, 1427-1433. https://doi.org/10.5897/AJAR2015.9610 
Joensuu, K., \& Sinkko, T. (2015). Environmental sustainability and improvement options for agribiomass chains: Straw and turnip rape. Biomass and Bioenergy, 83, 1-7. https://doi.org/10.1016/j.biombioe.2015.08.014

Juchen, C. R., Suszek, F. L., \& Vilas Boas, M. A. (2013). Irrigação por gotejamento para produção de alface fertirrigada com águas residuárias agroindustriais. Irriga, 18(1), 243-256. https://doi.org/10.15809/irriga. 2013 v18n2p243

Kalogirou, S. (2009). Thermal performance, economic and environmental life cycle analysis of thermosiphon solar water heaters. Solar Energy, 83, 39-48. https://doi.org/10.1016/j.solener.2008.06.005

Keller, J., \& Bliesner, R. D. (1990). Sprinkle and trickle irrigation. van Nostrand Reinhold, New York, USA. https://doi.org/10.1007/978-1-4757-1425-8

Keller, J., \& Karmeli, D. (1975). Trickle irrigation design. Glendora: Rain Bird Sprinkler Manufacturing.

Kelley, L. C., Gilbertson, E., Sheikh, A., Eppinger, S. D., \& Dubowsky, S. (2010). On the feasibility of solar-powered irrigation. Renew Sustain Energy, 14(9), 2669-2682. https://doi.org/10.1016/j.rser.2010. 07.061

Klein, M. R., Vilas Boas, M. A., Suszek, F. A., Szekut, F. D., Mello, E. L., Gomes, B. M., ... Zuculotto, T. (2015). Fertigation quality with drip irrigation system in grape orchard by using the process capability index. Journal of Food, Agriculture and Environment, 13, 179-183. https://doi.org/10.1234/4.2015.3981

Lise, W., \& Laan, J. V. der. (2015). Investment needs for climate change adaptation measures of electricity power plants in the EU. Energy for Sustainable Development, 28, 10-20. https://doi.org/10.1016/j.esd.2015.06.003

López-Mata, E., Tarjuelo, J. M., Juan, J. A. de, Ballesteros, R., \& Domínguez, R. A., (2010). Effect of irrigation uniformity on the profitability of crops. Agricultural Water Management, 98, 190-199. https://doi.org/ 10.1016/j.agwat.2010.08.006

Martins, F. R., \& Pereira, E. B. (2011). Estudo comparativo da confiabilidade de estimativas de irradiação solar para o sudeste brasileiro obtidas a partir de dados de satélite e por interpolação/extrapolação de dados de superfície. Revista Brasileira de Geofísica, 29, 265-276. https://doi.org/10.1590/S0102-261X2011000 200005

Martins, F. R., Guarnieri, R. A., \& Pereira, E. B. (2008). O aproveitamento da Energia Eólica. Revista Brasileira de Ensino de Física, 30, 1304. https://doi.org/10.1590/S1806-11172008000100005

Merrian, J. L., \& Keller, J. (1978). Farm irrigation system evaluation: A guide for management. Logan: Agricultural and Irrigation, Engineering Department, Utah State University.

Montgomery, D. C. (2009). In A. M. L. Farias, V. R. L. F. Flores, \& L. C. Laurencel (Trans.), Introdução ao controle estatístico de qualidade (4th ed.). Rio de Janeiro: Editora LTC.

Naspolini, H. F., Militão, H. S. G., \& Rüther, R. (2010). The role and benefits of solar water heating in the energy demands of low-income dwellings in Brazil. Energy Conversion and Management, 51, $2835-2845$. https://doi.org/10.1016/j.enconman.2010.06.021

NU (Nation United). (2015). Relatório de Desenvolvimento Humano. Retrived August 10, 2017, from http://www.pnud.org.br/hdr/arquivos/RDHglobais/hdr2015_ptBR.pdf

Oliveira, L. F. C., Ferreira, R. C., Almeida, R. A., Lobato, E. J. V., \& Medeiros, A. M. M. (2008). Potencial de redução do consumo de energia elétrica pela utilização de aquecedores solares no estado de Goiás. Engenharia Agrícola, 28, 406-416. https://doi.org/10.1590/S0100-69162008000300002

Puig-Bargués, J., Arbat, G., Elbana, M., Duran-Ros, M., Barragán, J., Ramírez de Cartagena, F., \& Lamm, F. R. (2010). Effect of flushing frequency on emitter clogging in micro-irrigation with effluents. Agricultural Water Management, 7, 883-891. https://doi.org/10.1016/j.agwat.2010.01.019

Ranquet Bouleau, C., Müller, T., \& Perona, P. (2016). Optimizing drip irrigation for eggplant crops in semi-arid zones usingevolving thresholds. Agricultural Water Management, 177, 54-65. https://oi.org/10.1016/ j.agwat.2016.06.019

Reca, J., Torrente, C., López-Luque, R., \& Martínez, J. (2016). Feasibility analysis of standalone direct pumping photovoltaic system for irrigation in Mediterranean greenhouses. Renewable Energy, 85, 1143-1154. https://doi.org/10.1016/j.renene.2015.07.056 
Sá, N. S. A. de. (2013) Irrigação e Pulverização: Características da irrigação por gotejamento. Retrieved from http://www.diadecampo.com.br/zpublisher/materias/Materia.asp?id=20643\&secao=Irriga $\%$ E7\%E3o $\% 20 \mathrm{e} \%$ 20Pulveriza $\%$ E7\%E3o

Santos, F. L. V. dos, Matos, E. dos R., Oliveira, R. G. de, Martins, R. F., Silva, A. O. da, \& Delmond, J. G. (2012). Uniformidade de aplicação em sistema de irrigação por gotejamento. VI Jornada Acadêmica.

Silva, R. A., \& Silva, A. M. (2003). Avaliação das características hidráulicas do Microdifusor autocompensante Dan Jet 7200. Ciência Agrotécnica, 27, 873-878. https://doi.org/10.1590/S1413-70542003000400020

Teixeira, M. B. (2006). Efeitos de dosagens extremas de cloro e pH na vazão de gotejadores autocompensantes (irrigação localizada) (Unpublished doctoral dissertation, Universidade de São Paulo, Piracicaba, Brasil).

Tessaro, E. (2012). Efeito da carga hidráulica na uniformidade da irrigação e fertirrigação em sistema de gotejamento (Unpublished master's thesis, Universidade Estadual do Oeste do Paraná, Cascavel, Brasil).

Thornley, P., Röder, M., \& Whittaker, C. (2015). How certain are greenhouse gas reductions from bioenergy? Life cycle assessment and uncertainty analysis of wood pellet-to-electricity supply chains from forest residues. Biomass and Bioenergy, 79, 50-63. https://doi.org/10.1016/j.biombioe.2015.03.030

Tomalsquim, M. T. (2003). Fontes Renováveis de Energia no Brasil. Rio de Janeiro: Interciência.

Upadhyay, B. (2003). Drip irrigation: An appropriate technology for women. Appropriate Technology, 30(4), 31-37. Retrieved from http://hdl.handle.net/10568/41226

Verma, S., Tsephal, S., \& Jose, T. (2004). Pepsee systems: Grass root innovation underground water stress. Water Policy, 6, 1-16. Retrieved from http://hdl.handle.net/10568/41153

Zago, E. A., (2017). Desempenho de um sistema de irrigação por gotejamento utilizando energia fotovoltaica (Unpublished master's thesis, Universidade Estadual do Oeste do Paraná, Cascavel, Brasil).

\section{Copyrights}

Copyright for this article is retained by the author (s), with first publication rights granted to the journal.

This is an open-access article distributed under the terms and conditions of the Creative Commons Attribution license (http://creativecommons.org/licenses/by/4.0/). 